\title{
Article
}

\section{Methylglyoxal (MGO) in Italian Honey}

\author{
Valentina Terio ${ }^{1}\left(\right.$, Giancarlo Bozzo ${ }^{1}\left(\mathbb{D}\right.$, Edmondo Ceci $^{1}$, Alessandra Emilia Savarino ${ }^{1}$, Roberta Barrasso ${ }^{1}{ }^{1}$, \\ Angela Di Pinto ${ }^{1}{ }^{1}$, Anna Mottola ${ }^{1}\left(\mathbb{D}\right.$, Patrizia Marchetti ${ }^{2}$, Giuseppina Tantillo ${ }^{3}$ and Elisabetta Bonerba ${ }^{1, *}$ (i)
}

1 Department of Veterinary Medicine (DIMEV), University of Bari Aldo Moro, Strada Provinciale per Casamassima km 3, 70010 Valenzano (Bari), Italy; valentina.terio@uniba.it (V.T.); giancarlo.bozzo@uniba.it (G.B.); edmondo.ceci@uniba.it (E.C.); savarino.alessandra@virgilio.it (A.E.S.); roberta.barrasso@uniba.it (R.B.); angela.dipinto@uniba.it (A.D.P.); anna.mottola@uniba.it (A.M.)

2 Specialization Degree in "Inspection of Food of Animal Origin", Department of Veterinary Medicine (DIMEV), University of Bari Aldo Moro, Strada Provinciale per Casamassima km 3, 70010 Valenzano (Bari), Italy; patrizia.marchetti@uniba.it

3 Interdisciplinary Department of Medicine (DIM), University of Bari Aldo Moro, Piazza Giulio Cesare 11, 70124 Bari, Italy; giuseppina.tantillo@uniba.it

* Correspondence: elisabetta.bonerba@uniba.it; Tel.: +39-080-544-3851

Citation: Terio, V.; Bozzo, G.; Ceci, E.; Savarino, A.E.; Barrasso, R.; Di Pinto, A.; Mottola, A.; Marchetti, P.; Tantillo, G.; Bonerba, E. Methylglyoxal (MGO) in Italian Honey. Appl. Sci. 2021, 11, 831. https://doi.org/10.3390/ app11020831

Received: 2 December 2020 Accepted: 14 January 2021 Published: 17 January 2021

Publisher's Note: MDPI stays neutral with regard to jurisdictional clai$\mathrm{ms}$ in published maps and institutional affiliations.

Copyright: $\odot 2021$ by the authors. Licensee MDPI, Basel, Switzerland. This article is an open access article distributed under the terms and conditions of the Creative Commons Attribution (CC BY) license (https:// creativecommons.org/licenses/by/ $4.0 /)$.
Featured Application: This work proposes an evaluation of Italian honeys with particular reference to the presence of MGO, which aims to improve the knowledge of the composition of Italian honey, thereby contributing to promote and highlight the value of this specific production sector. Further studies are needed to understand if the antibacterial activity of Italian honeys also depends on the presence of methylglyoxal.

Abstract: Methylglyoxal (MGO) is recognized as being the bioactive component responsible for the antibacterial activity of mānuka honey. MGO content was investigated by high-performance liquid chromatography (HPLC-UV), in isocratic elution, to assess the occurrence of this compound in monoand multi-floral honey samples representative of different botanical and geographic origins in Italy. Specifically, 110 honey samples from sweet cherry tree (Prunus avium L.), thyme (Thymus vulgaris L.), almond tree (Prunus amygdalus L.), eucalyptus (Eucalyptus camaldulensis L.), coriander (Coriandrum sativum L.), cornflower (Centaurea cyanus L.), thistle (Silybum marianum L.), acacia (Robinia pseudoacacia L.), citrus, honeydew and multifloral honey were considered. The amount of MGO found in different types of honey was ranging from 0.4 to $24.1 \mathrm{mg} / \mathrm{kg}$. This study provides, for the first time, data on MGO levels in Italian cherry and almond honey, which showed higher concentrations of MGO compared to honeys from other botanical species.

Keywords: Italian honey; methylglyoxal; HPLC

\section{Introduction}

Honey is a natural source of macro and micro-nutrients and many biologically active compounds [1,2]. Already known since ancient times, honey has recently been defined, by numerous scientific studies, as a functional food [3].

Recent studies have shown that, like other hive products, honey has various benefits for human health, such as antioxidant, anti-inflammatory, antimicrobial and bacteriostatic effects [4-7]. For these reasons, honeybee products are already widely used as ingredients in the field of cosmetics and nutraceuticals $[3,8,9]$. In the last few years, high consumer demand for natural healthy products has increased research interest in the antibacterial activity of honey for its possible clinical applications [6,10-13].

The biological effects of honey are due to its specific physico-chemical composition. In particular, its antioxidant activity $[4,14]$ is related to the concentration of the polyphenolic compounds [15-17], ascorbic acid, protein and carotenoid, and glucose oxidase and catalase $[18,19]$. Several studies have also shown that the presence of flavonoids and phenolic 
acids is also responsible for its anti-inflammatory effect. Among these, galangin and chrysin are involved respectively in the inhibition of cyclooxygenase (COX) and lipo-oxygenase activity, and the suppression both of COX-2 pro-inflammatory activities and of inducible nitric oxide synthase (iNOS), the enzyme involved in the inflammatory process [3,20,21].

Regarding antibacterial activity, many studies have highlighted honey's broad- spectrum action against various agents (bacteria, viruses, fungi) [5]. Its antimicrobial effect involves several mechanisms attributed to various synergistic factors [22,23], such as low $\mathrm{pH}$, osmotic pressure, high sugar concentration and the presence of low moisture contents, hydrogen peroxide $\left(\mathrm{H}_{2} \mathrm{O}_{2}\right)$, phenolic acids, flavonoid, lysozyme and bee defensin-1 [2,6,23-26]. Generally, hydrogen peroxide is used to investigate this property$\mathrm{H}_{2} \mathrm{O}_{2}$ derives, from the action of the enzyme, glucose oxidase, added by bees, which converts glucose into $\mathrm{H}_{2} \mathrm{O}_{2}$ and gluconic acid [6].

Even though different honeys have shown efficacy in the treatment of a number of infections, in recent years researchers' attention has focused on one particular substance contained in some types of honey, methylglyoxal (MGO), which shows greater antibacterial activity compared to non-MGO honey. 1,2-dicarbonyl compounds such as 3-deoxyglucosone (3-DG ), glyoxal (GO), and methylglyoxal (MGO) are typically formed during the Maillard reaction or caramelization reactions as degradation products in many foods and beverages, such as bread, yogurt, wine, beer and other foodstuffs. These reactive compounds can also be formed endogenously by cell metabolism, glucose oxidation and lipid peroxidation, and are thus potential precursors of advanced glycation end products (AGEs). AGEs are complex heterogeneous compounds related to protein cross-linking and the alteration of the function of many important enzymes or immunological proteins, with adverse effects on immune response [27]. AGEs are also involved in the progression of chronic diseases and diabetes complications. Not all AGEs have been identified and the occurrence of AGEs in honey has been poorly investigated.

Scientists have produced very different assessments of the ingestion of high MGO concentrations as potentially harmful to intestinal microbiota [28].

Methylglyoxal is a reactive $\alpha$-dicarbonyl compound present in high levels of up to $800 \mathrm{mg} / \mathrm{kg}$ in mānuka honey [29], derived from the mānuka tree (Leptospermum scoparium) in New Zealand, and has been identified as being directly responsible for the "non-peroxide" antibacterial activity. Mānuka honey has shown strong activity against a wide range of microorganisms, including multiresistant strains of important human pathogens [30-33].

Nectar source is decisive in honey MGO concentration because methylglyoxal is a signaling molecule in plants subjected to abiotic stress. Indeed, many studies have shown that the composition and volume of nectar are influenced by environmental variables (water stress, temperatures, soil nutrients) or plant-specific factors (flower age, sex and genotypic variability) [34]. Consequently, MGO concentrations in honey vary not only from year to year, but also from one country to the next, given that the composition of honey, even from the same cultivar, is strictly linked to its area of production, and its organoleptic characteristics reflect the vegetational diversity of the environment of origin. The presence of MGO in honey has been attributed to the phenomenon of sugar degradation in the course of caramelization [35], but successive studies have shown that the high levels of this compound in mānuka honey are a consequence of the presence of dihydroxyacetone (DHA) [29,36,37], identified as a direct precursor for MGO formation. DHA is produced by the plant or by microbes present in the flower [38], and is contained in mānuka nectar; DHA dehydration increases the MGO levels during honey maturation [36].

Considering the scientific interest in honey's therapeutic effects, in the present study the qualitative and quantitative presence of MGO was investigated in multifloral and unifloral Italian honeys. 


\section{Materials and Methods}

\subsection{Sampling}

In total, 110 Italian honey samples, collected in 2019, were purchased from different specialized dealers and supermarkets. From Apulia, a region particularly suited to honey production, samples were supplied by beekeepers belonging to the association UNAAPI, a confederation of beekeepers present throughout the region. Specifically, samples of honey made from sweet cherry tree (Prunus avium L.), thyme (Thymus vulgaris L.), almond tree (Prunus amygdalus L.), eucalyptus (Eucalyptus camaldulensis L.), coriander (Coriandrum Sativum L.), cornflower (Centaurea cyanus L.), thistle (Silybum marianum L.), acacia (Robinia pseudoacacia L.), citrus, honeydew and multifloral honey were collected. Details of honey samples analyzed are reported in Table 1. The identification of the honey sample's floral origin was assessed by palynological analyses (CRA-API Bologna), and confirmed, only for Apulian honey samples, by sensorial analyses performed by a specialized expert assessor selected from the professional trained members belonging to the Italian Register of Experts in the Sensory Analysis of Honey.

Table 1. Geographical origin of Italian honey.

\begin{tabular}{|c|c|c|}
\hline Floral Origin & Geographical Origin & Number of Samples \\
\hline Sweet Cherry & Apulia & 10 \\
\hline \multirow{3}{*}{ Thyme } & Apulia & 5 \\
\hline & Sardinia & 3 \\
\hline & Sicily & 2 \\
\hline \multirow[b]{2}{*}{ Almond } & Apulia & 6 \\
\hline & Sicily & 4 \\
\hline \multirow{6}{*}{ Eucalyptus } & Apulia & 3 \\
\hline & Calabria & 2 \\
\hline & Lazio & 2 \\
\hline & Sardinia & 1 \\
\hline & Sicily & 1 \\
\hline & Tuscany & 1 \\
\hline \multirow{4}{*}{ Coriander } & Abruzzo & 2 \\
\hline & Apulia & 4 \\
\hline & Emilia Romagna & 2 \\
\hline & Marche & 2 \\
\hline \multirow{4}{*}{ Cornflower } & Apulia & 4 \\
\hline & Lazio & 2 \\
\hline & Marche & 2 \\
\hline & Tuscany & 2 \\
\hline \multirow{3}{*}{ Thistle } & Apulia & 2 \\
\hline & Calabria & 4 \\
\hline & Sicily & 4 \\
\hline \multirow{7}{*}{ Acacia } & Sardinia & 2 \\
\hline & Abruzzo & 1 \\
\hline & Apulia & 2 \\
\hline & Campania & 1 \\
\hline & Piedmont & 1 \\
\hline & Tuscany & 2 \\
\hline & Veneto & 1 \\
\hline \multirow{4}{*}{ Citrus } & Apulia & 4 \\
\hline & Basilicata & 2 \\
\hline & Calabria & 2 \\
\hline & Sicily & 2 \\
\hline
\end{tabular}


Table 1. Cont.

\begin{tabular}{ccc}
\hline Floral Origin & Geographical Origin & Number of Samples \\
\hline & Abruzzo & 1 \\
& Aosta Valley & 2 \\
Honeydew & Apulia & 2 \\
& Emilia Romagna & 1 \\
& Tuscany & 2 \\
& Trentino Alto Adige & 2 \\
\hline \multirow{3}{*}{ Multifloral } & Apulia & 4 \\
& Campania & 2 \\
& Calabria & 2 \\
\hline
\end{tabular}

For each type of honey analyzed, 10 samples were collected and stored in a dark place at room temperature until analysis.

Before assessing the MGO content, some physicochemical properties of the samples (aw and pH) and the composition criteria reported in Council Directive 2001/110/EC [39] relating to honey (hydroxymethylfurfural (HMF), electrical conductivity, moisture content, diastase) were characterized.

\subsection{Chemicals}

All chemicals used were of HPLC grade. Methylglyoxal 40\% $w / w$, methanol, acetonitrile, water, orthophenylendiamine (OPD) and acetate buffer were purchased from Aldrich-Fluka-Sigma S.r.l. (Milan, Italy).

The distilled water used in the extraction process was purified and deionized using a Milli-Q Plus appliance (Millipore, Bedford, MA, USA).

Phadebas Honey Diastase Test tablets were purchased from Phadebas (@, Sweden).

\subsection{Physicochemical Characterization of Honey Samples}

Physicochemical parameters were analyzed according to "The Official Methods of Analysis of Association of Official Analytical Chemists", [40] and "The Harmonized Methods of the European Honey Commission" [41].

The honey samples were homogenized by stirring thoroughly.

HMF was determined by HPLC-UV using as the isocratic mobile phase water/ methanol $(90: 10 \mathrm{v} / \mathrm{v})$ with a flow rate of $1.0 \mathrm{~mL} / \mathrm{min}$. The column used was a ZORBAX (Eclipse Plus C18, $4.6 \times 150 \mathrm{~mm}, 5 \mu \mathrm{m}$ particle size), from Agilent (Agilent Technologies, Santa Clara, CA, USA), and the detector was set to $285 \mathrm{~nm}$ [42].

Water activity was measured using an electronic dew-point water activity meter $\left(25 \pm 0.2^{\circ} \mathrm{C}\right)$ (Aqualab Series 4 mod. TE Decagon Devices, Pullman, WA, USA), with a temperature-controlled system [43].

Electrical conductivity was determined at $20{ }^{\circ} \mathrm{C}$ by conductimetry (Crison Basic 30, Crison Instrument, ITALY). Results were expressed in microSiemens per centimeter $(\mu \mathrm{S} / \mathrm{cm})$.

Moisture content was analyzed at $20^{\circ} \mathrm{C}$ with an Abbe type refractometer (PDT/001 Atago, Bellevue, Washington, USA), equipped with a thermometer having a graduation of $0.5^{\circ} \mathrm{C}$ and a resolution of $2 \times 10^{-4}$ units of refraction index (RI). Results were reported as percentages obtained from the Chat table by using the Wedmore method [44].

Measurements of $\mathrm{pH}$ were performed with a $\mathrm{pH}$ meter (Orion420 A) in a solution containing $10 \mathrm{~g}$ of each honey sample in $75 \mathrm{~mL}$ of Milli-Q grade water, by using the White method [45]. 
The diastase activity was assessed by Phadebas tablets as recommended by the International Honey Commission [41]. Phadebas Honey Diastase Tests (®), Sweden) were used according to the manufacturer instructions $-5 \mathrm{~mL}$ of $1 \%$ honey solution in $0.1 \mathrm{M}$ acetate buffer ( $\mathrm{pH}$ 5.2) was prepared and transferred to a test tube; after incubation at $40{ }^{\circ} \mathrm{C}$ for $5 \mathrm{~min}$, the Phadebas tablet was added. Then the sample was reincubated for $30 \mathrm{~min}$ at $40{ }^{\circ} \mathrm{C}$. Finally, $1 \mathrm{~mL}$ of $0.5 \mathrm{M} \mathrm{NaOH}$ was added to stop the reaction. The absorbance was measured at $620 \mathrm{~nm}$, after samples filtration (filter paper), with BioMate $160 \mathrm{UV}$-Visible Spectrophotometer (Thermo Scientific, Waltham, MA, USA).

All analyses were performed in triplicate.

\subsection{Analytical RP-HPLC}

To determine methylglyoxal content, a derivatization reaction with o-phenylenediamine (OPD) was carried out, giving rise to the quinoxaline adduct. Samples were incubated for $16 \mathrm{~h}$ with $2 \% \mathrm{w} / \mathrm{v}$ OPD in phosphate buffer $0.5 \mathrm{M}$ ( $\mathrm{pH} 6.5)$. The reaction was performed at room temperature, in dark conditions. The samples were examined using an Agilent HPLC (1260 Infinity, Agilent Technologies, Santa Clara, CA, USA) equipped with a $20 \mu \mathrm{L}$ Rheodyne injection loop, a Multiple Wavelength detector and a reversed phase column (Synergi ${ }^{\mathrm{TM}}$ Hydro-RP $4 \mu \mathrm{m} 150 \times 4.6 \mathrm{~mm}$, Phenomenex). An isocratic elution was performed at room temperature with a flow rate of $0.9 \mathrm{~mL} / \mathrm{min}$, using a mobile phase (Water/ACN $75 / 25)$. The column effluent was constantly monitored at $263 \mathrm{~nm}$ and the OPD derivative of methylglyoxal was eluted after $3.50 \mathrm{~min}$. The ChemStation software for LC systems (Agilent Technologies) was used for data acquisition and processing. Methylglyoxal quantification was performed by comparing the peak areas with those acquired using the standard compound eluted in the same conditions. A linear response was observed for the standard curve $\left(R^{2}=0.995\right)$. Each analysis was performed in triplicate and results were reported as mean \pm standard deviation.

The limit of detection (LOD) and limit of quantification (LOQ) of the analytical method applied were calculated and were, respectively, $0.04 \mathrm{mg} / \mathrm{kg}$ and $0.12 \mathrm{mg} / \mathrm{kg}$.

After evaluating the presence of MGO, only samples that showed the highest concentration of MGO were analyzed for minimum inhibitory concentration (MIC).

\subsection{Statistical Analysis}

The MGO data were subjected to analysis of variance (ANOVA) using the GLM by SAS software (SAS 9.4), according to the following model:

$$
\mathrm{y}_{\mathrm{ij}}=\mu+\mathrm{F}_{\mathrm{i}}+\varepsilon_{\mathrm{ij}}
$$

where $y_{i j}$ represents the MGO as dependent variables, $\mu$ is the overall mean, $\mathrm{F}$ is the effect of the $\mathrm{i}^{\mathrm{th}}$ floral origin $(\mathrm{i}=1, \ldots 11)$, and $\varepsilon_{\mathrm{ij}}$ is the error term. MGO values were expressed as quadratic means and standard error of the mean.

\section{Results}

\subsection{Physicochemical Characterization of Honey Samples}

Table 2 shows the results obtained for each type of honey with mean \pm SD and minimum and maximum value. 


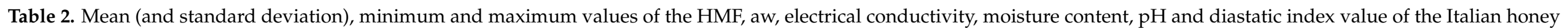
samples.

\begin{tabular}{|c|c|c|c|c|c|c|c|c|c|}
\hline \multirow{2}{*}{$\begin{array}{l}\text { Physicochemical } \\
\text { Parameters }\end{array}$} & \multicolumn{3}{|c|}{ Sweet Cherry } & \multicolumn{3}{|c|}{ Thyme } & \multicolumn{3}{|c|}{ Almond } \\
\hline & Mean \pm SD & Min & Max & Mean \pm SD & Min & Max & Mean \pm SD & Min & Max \\
\hline HMF (mg/kg) & $21.59 \pm 2.10$ & 19.01 & 24.39 & $8.64 \pm 1.74$ & 5.86 & 10.97 & $12.41 \pm 1.61$ & 10.09 & 14.29 \\
\hline aw & $0.61 \pm 0.07$ & 0.47 & 0.7 & $0.62 \pm 0.08$ & 0.51 & 0.71 & $0.55 \pm 0.04$ & 0.49 & 0.62 \\
\hline Electrical conductivity $(\mathrm{ms} / \mathrm{cm})$ & $0.54 \pm 0.09$ & 0.4 & 0.64 & $0.44 \pm 0.04$ & 0.39 & 0.49 & $0.5 \pm 0.07$ & 0.42 & 0.65 \\
\hline Moisture content (\%) & $16.47 \pm 0.32$ & 16 & 16.92 & $16.18 \pm 0.87$ & 15.13 & 17.11 & $14.87 \pm 0.52$ & 14.3 & 15.7 \\
\hline $\mathrm{pH}$ & $4.05 \pm 0.07$ & 3.88 & 4.09 & $4.11 \pm 0.17$ & 3.87 & 4.32 & $4.58 \pm 0.16$ & 4.32 & 4.77 \\
\hline Diastatic index values (Schade number) & $20.86 \pm 5.94$ & 11.4 & 31.2 & $30.33 \pm 4.66$ & 25.6 & 38.33 & $23.2 \pm 5.49$ & 15.2 & 30.4 \\
\hline \multirow{2}{*}{$\begin{array}{c}\text { Physicochemical } \\
\text { Parameters }\end{array}$} & \multicolumn{3}{|c|}{ Eucalyptus } & \multicolumn{3}{|c|}{ Coriander } & \multicolumn{3}{|c|}{ Cornflower } \\
\hline & Mean \pm SD & Min & Max & Mean \pm SD & Min & Max & Mean \pm SD & Min & $\operatorname{Max}$ \\
\hline $\operatorname{HMF}(\mathrm{mg} / \mathrm{kg})$ & $28.94 \pm 6.83$ & 16.02 & 39.14 & $4.14 \pm 1.3$ & 2.31 & 5.72 & $21.52 \pm 1.15$ & 20.18 & 24.18 \\
\hline aw & $0.6 \pm 0.05$ & 0.51 & 0.67 & $0.47 \pm 0.04$ & 0.42 & 0.52 & $0.59 \pm 0.04$ & 0.51 & 0.64 \\
\hline Electrical conductivity $(\mathrm{ms} / \mathrm{cm})$ & $0.74 \pm 0.04$ & 0.65 & 0.78 & $0.33 \pm 0.02$ & 0.3 & 0.37 & $0.5 \pm 0.05$ & 0.43 & 0.59 \\
\hline Moisture content $(\%)$ & $16.29 \pm 0.41$ & 15.79 & 17.01 & $17.31 \pm 0.4$ & 16.6 & 17.8 & $17.88 \pm 0.43$ & 17.4 & 18.5 \\
\hline Diastatic index values (Schade number) & $25.65 \pm 4.07$ & 17.8 & 31.4 & $17.3 \pm 3.6$ & 10.4 & 22.6 & $19.05 \pm 4.95$ & 11.2 & 26.4 \\
\hline
\end{tabular}


Table 2. Cont.

\begin{tabular}{|c|c|c|c|c|c|c|c|c|c|}
\hline \multirow{2}{*}{$\begin{array}{l}\text { Physicochemical } \\
\text { Parameters }\end{array}$} & \multicolumn{3}{|c|}{ Thistle } & \multicolumn{3}{|c|}{ Acacia } & \multicolumn{3}{|c|}{ Citrus } \\
\hline & Mean \pm SD & Min & Max & Mean \pm SD & Min & Max & Mean \pm SD & Min & $\operatorname{Max}$ \\
\hline HMF (mg/kg) & $14.29 \pm 1.9$ & 10.74 & 16.11 & $7.04 \pm 2.11$ & 5.09 & 11.28 & $11.67 \pm 1.64$ & 8.65 & 14.56 \\
\hline Electrical conductivity $(\mathrm{ms} / \mathrm{cm})$ & $0.38 \pm 0.03$ & 0.32 & 0.42 & $0.22 \pm 0.06$ & 0.11 & 0.29 & $0.24 \pm 0.08$ & 0.09 & 0.34 \\
\hline Moisture content $(\%)$ & $18.38 \pm 0.84$ & 17.13 & 19.44 & $18.24 \pm 0.47$ & 17.28 & 18.7 & $17.73 \pm 1.25$ & 14.9 & 20.56 \\
\hline $\mathrm{pH}$ & $3.99 \pm 0.05$ & 3.88 & 4.03 & $3.92 \pm 0.26$ & 3.44 & 4.19 & $4.11 \pm 0.15$ & 3.94 & 4.35 \\
\hline Diastatic index values (Schade number) & $19.37 \pm 5.2$ & 12.9 & 28.6 & $8.62 \pm 2.48$ & 5.3 & 12.2 & $9.8 \pm 3.44$ & 4.5 & 14.2 \\
\hline \multirow{2}{*}{$\begin{array}{c}\text { Physicochemical } \\
\text { Parameters }\end{array}$} & \multicolumn{3}{|c|}{ Honeydew } & \multicolumn{3}{|c|}{ Multifloral } & & & \\
\hline & Mean \pm SD & Min & Max & Mean \pm SD & Min & Max & & & \\
\hline $\mathrm{HMF}(\mathrm{mg} / \mathrm{kg})$ & $5.72 \pm 1.35$ & 3.17 & 6.69 & $24.38 \pm 1.70$ & 20.97 & 26.01 & & & \\
\hline aw & $0.52 \pm 0.08$ & 0.32 & 0.61 & $0.52 \pm 0.04$ & 0.46 & 0.56 & & & \\
\hline Electrical conductivity $(\mathrm{ms} / \mathrm{cm})$ & $1.07 \pm 0.17$ & 0.83 & 1.31 & $0.6 \pm 0.14$ & 0.32 & 0.75 & & & \\
\hline Moisture content $(\%)$ & $18.03 \pm 0.31$ & 17.54 & 18.61 & $16.83 \pm 0.58$ & 16.21 & 17.66 & & & \\
\hline Diastatic index values (Schade number) & $22.94 \pm 6.68$ & 14.3 & 33.2 & $22.83 \pm 4.24$ & 14.9 & 27.6 & & & \\
\hline
\end{tabular}


The physicochemical parameters assessed in honey samples (i.e., HMF, electrical conductivity, moisture content, diastase) were in compliance with the composition criteria for honey fixed in Council Directive 2001/110/EC [39] relating to honey.

HMF is derived from the decomposition of fructose in acid conditions. In honey it can be used as a good marker of heating and storage time at elevated temperatures [42]. None of the samples analyzed had values of HMF higher than the maximum limit of $40 \mathrm{mg} / \mathrm{kg}$ permitted by European standards [39].

The electrical conductivity of the honey is a parameter linked to mineral salts, ash, complex sugars, organic acids and proteins concentration, and is strongly influenced by the floral origin. The value set in Council Directive 2001/110/EC [39] is no more than $0.8 \mathrm{mS} / \mathrm{cm}$, with some exceptions (e.g., in honeydew honey, no less than $0.8 \mathrm{mS} / \mathrm{cm}$ ). In the analyzed honeys very different values were found, ranging between 0.09 and $0.7 \mathrm{mS} / \mathrm{cm}$ (respectively for citrus and eucalyptus), owing to the different origins of the samples, and between 0.83 and $1.31 \mathrm{mS} / \mathrm{cm}$ for honeydew honey.

The moisture content is a parameter that strongly influences the shelf life of honey and some organoleptic characteristics, such as viscosity and palatability. For the Council Directive 2001/110/EC [39], the maximum permitted limit of moisture content is $20 \%$; indeed, higher values than those established by law can facilitate osmophilic yeast fermentation. All analyzed samples, except one (20.56\% for citrus honey), fulfilled this criterion, with a range between $13.4 \%$ (min value for cornflower honey) and $19.44 \%$ (max value for thistle honey).

Diastase is a natural enzyme of honey: its content depends mainly on the floral sources and nectar collection period, and is used as an index of overheating and/or storage for too long [46,47]. According to the EU Honey Directive [39], the diastase number (DN) is legally regulated according to the Schade scale-for honey, with the exception of baker's honey/industrial honey, a minimum activity of $8 \mathrm{DN}$ (Schade scale) is fixed. All analyzed samples were in compliance with this regulation.

\subsection{MGO Content}

In this study, the concentration of MGO $(\mathrm{mg} / \mathrm{kg}$ ) was determined in multifloral and unifloral Italian honey, with mean $\pm \mathrm{SD}$ being reported in Table 3 .

Table 3. Levels of methylglyoxal (MGO) in Italian honey samples.

\begin{tabular}{|c|c|c|c|}
\hline Honey Samples & Floral Origin & Geographical Origin & MGO (mg/kg) \\
\hline 1 & \multirow{10}{*}{ Sweet Cherry } & \multirow{10}{*}{ Apulia } & 23 \\
\hline 2 & & & 18.2 \\
\hline 3 & & & 17.9 \\
\hline 4 & & & 17.9 \\
\hline 5 & & & 17.8 \\
\hline 6 & & & 10.3 \\
\hline 7 & & & 22.9 \\
\hline 8 & & & 21 \\
\hline 9 & & & 20.6 \\
\hline \multirow[t]{2}{*}{10} & & & 16.6 \\
\hline & & Mean \pm SD & $18.62 \pm 3.69$ \\
\hline 11 & \multirow{10}{*}{ Thyme } & \multirow{5}{*}{ Apulia } & 17 \\
\hline 12 & & & 7.21 \\
\hline 13 & & & 9.4 \\
\hline 14 & & & 8.6 \\
\hline 15 & & & 6.8 \\
\hline 16 & & \multirow{3}{*}{ Sardinia } & 7.4 \\
\hline 17 & & & 9.1 \\
\hline 18 & & & 8.4 \\
\hline 19 & & \multirow{2}{*}{ Sicily } & 7.5 \\
\hline 20 & & & 8.8 \\
\hline
\end{tabular}


Table 3. Cont.

\begin{tabular}{|c|c|c|c|}
\hline Honey Samples & Floral Origin & Geographical Origin & MGO (mg/kg) \\
\hline & & Mean \pm SD & $9.02 \pm 2.94$ \\
\hline 21 & \multirow{10}{*}{ Almond } & \multirow{6}{*}{ Apulia } & 19.4 \\
\hline 22 & & & 24.1 \\
\hline 23 & & & 19.1 \\
\hline 24 & & & 23.3 \\
\hline 25 & & & 17.1 \\
\hline 26 & & & 20 \\
\hline 27 & & \multirow{4}{*}{ Sicily } & 12 \\
\hline 28 & & & 11.6 \\
\hline 29 & & & 16 \\
\hline \multirow[t]{2}{*}{30} & & & 16.2 \\
\hline & & Mean \pm SD & $17.88 \pm 4.18$ \\
\hline 31 & \multirow{10}{*}{ Eucalyptus } & \multirow{3}{*}{ Apulia } & 13 \\
\hline 32 & & & 11.6 \\
\hline 33 & & & 10.4 \\
\hline 34 & & Tuscany & 12.5 \\
\hline 35 & & Sicily & 9.9 \\
\hline 36 & & \multirow{2}{*}{ Calabria } & 12.7 \\
\hline 37 & & & 10.2 \\
\hline 38 & & \multirow[b]{2}{*}{ Lazio } & 12.3 \\
\hline 39 & & & 11.8 \\
\hline \multirow[t]{2}{*}{40} & & Sardinia & 12 \\
\hline & & Mean \pm SD & $11.64 \pm 1.10$ \\
\hline 41 & \multirow{10}{*}{ Coriander } & \multirow{4}{*}{ Apulia } & 6.9 \\
\hline 42 & & & 6.7 \\
\hline 43 & & & 6.6 \\
\hline 44 & & & 9.8 \\
\hline 45 & & \multirow{2}{*}{ Marche } & 6.9 \\
\hline 46 & & & 6.5 \\
\hline 47 & & \multirow{2}{*}{ Emilia Romagna } & 8.4 \\
\hline 48 & & & 6.9 \\
\hline 49 & & \multirow{2}{*}{ Abruzzo } & 7.8 \\
\hline \multirow[t]{2}{*}{50} & & & 6.4 \\
\hline & & Mean \pm SD & $7.29 \pm 1.08$ \\
\hline 51 & \multirow{10}{*}{ Cornflower } & \multirow{4}{*}{ Apulia } & 9.7 \\
\hline 52 & & & 9.3 \\
\hline 53 & & & 8.8 \\
\hline 54 & & & 14.8 \\
\hline 55 & & \multirow{2}{*}{ Tuscany } & 8.1 \\
\hline 56 & & & 10.1 \\
\hline 57 & & \multirow{2}{*}{ Lazio } & 8.7 \\
\hline 58 & & & 9.9 \\
\hline 59 & & Marche & 13.8 \\
\hline 60 & & Marche & 9.6 \\
\hline & & Mean \pm SD & $10.28 \pm 2.22$ \\
\hline 61 & & Apulia & 8.9 \\
\hline 62 & & Apulia & 8.1 \\
\hline 63 & & & 8.6 \\
\hline 64 & & Calahria & 7.9 \\
\hline 65 & Thistle & Calabria & 8.5 \\
\hline 66 & & & 8.9 \\
\hline 67 & & & 8.2 \\
\hline 68 & & Sicily & 8.7 \\
\hline 69 & & Siciny & 8.3 \\
\hline 70 & & & 8.8 \\
\hline
\end{tabular}


Table 3. Cont.

\begin{tabular}{|c|c|c|c|}
\hline Honey Samples & Floral Origin & Geographical Origin & MGO (mg/kg) \\
\hline & & Mean \pm SD & $8.49 \pm 0.35$ \\
\hline 71 & \multirow{10}{*}{ Acacia } & \multirow{2}{*}{ Apulia } & 15 \\
\hline 72 & & & 6.6 \\
\hline 73 & & \multirow[b]{2}{*}{ Sardinia } & 5.2 \\
\hline 74 & & & 7.2 \\
\hline 75 & & \multirow{2}{*}{ Tuscany } & 6.9 \\
\hline 76 & & & 14.1 \\
\hline 77 & & Piedmont & 5.8 \\
\hline 78 & & Abruzzo & 6.8 \\
\hline 79 & & Veneto & 15.2 \\
\hline \multirow[t]{2}{*}{80} & & Campania & 5.9 \\
\hline & & Mean \pm SD & $8.87 \pm 4.12$ \\
\hline 81 & \multirow{10}{*}{ Citrus } & \multirow{4}{*}{ Apulia } & 7.7 \\
\hline 82 & & & 6.9 \\
\hline 83 & & & 4.7 \\
\hline 84 & & & 4.6 \\
\hline 85 & & \multirow{2}{*}{ Basilicata } & 4.5 \\
\hline 86 & & & 2.8 \\
\hline 87 & & \multirow{2}{*}{ Calabria } & 0.4 \\
\hline 88 & & & 2.9 \\
\hline 89 & & \multirow{2}{*}{ Sicily } & 6.7 \\
\hline \multirow[t]{2}{*}{90} & & & 3.9 \\
\hline & & Mean \pm SD & $4.51 \pm 2.2$ \\
\hline 91 & \multirow{10}{*}{ Honeydew } & Abruzzo & 9.9 \\
\hline 92 & & \multirow{2}{*}{ Apulia } & 5.9 \\
\hline 93 & & & 5.9 \\
\hline 94 & & Emilia Romagna & 5.7 \\
\hline 95 & & \multirow{2}{*}{ Aosta Valley } & 6.6 \\
\hline 96 & & & 5.5 \\
\hline 97 & & \multirow{2}{*}{ Trentino Alto Adige } & 9.2 \\
\hline 98 & & & 5.7 \\
\hline 99 & & \multirow{2}{*}{ Tuscany } & 6.2 \\
\hline \multirow[t]{2}{*}{100} & & & 7.8 \\
\hline & & Mean \pm SD & $6.84 \pm 1.58$ \\
\hline 101 & \multirow{10}{*}{ Multifloral } & \multirow{4}{*}{ Apulia } & 18.4 \\
\hline 102 & & & 11 \\
\hline 103 & & & 6.5 \\
\hline 104 & & & 6.3 \\
\hline 105 & & \multirow{2}{*}{ Campania } & 12.9 \\
\hline 106 & & & 7.8 \\
\hline 107 & & \multirow{2}{*}{ Calabria } & 9.9 \\
\hline 108 & & & 10.4 \\
\hline 109 & & \multirow{2}{*}{ Emilia Romagna } & 8.8 \\
\hline 110 & & & 7.2 \\
\hline & & Mean \pm SD & $9.92 \pm 3.65$ \\
\hline
\end{tabular}

The study revealed variable amounts of MGO in different types of honey, with concentrations ranging from 0.4 to $9.8 \mathrm{mg} / \mathrm{kg}$ in citrus, thistle and coriander honey. The MGO levels in thyme honey ranged from 6.8 to $17 \mathrm{mg} / \mathrm{kg}$.

In disagreement with Arena et al. [48], in our study we observed higher levels of MGO in eucalyptus honey, ranging from 9.9 to $13 \mathrm{mg} / \mathrm{kg}$. In cornflower honey, the MGO content ranged from 8.1 to $14.8 \mathrm{mg} / \mathrm{kg}$. In acacia honey it was between 5.2 and $15.2 \mathrm{mg} / \mathrm{kg}$, in honeydew honey the content ranged from 5.5 to 9.9 , and in multifloral honey it was 
between 6.3 and $18.4 \mathrm{mg} / \mathrm{kg}$. Cherry and almond honeys showed the highest upper ranges of MGO levels-23 and $24.1 \mathrm{mg} / \mathrm{kg}$, respectively.

The statistical analysis is reported in Table 4.

Table 4. MGO data statistical analysis.

\begin{tabular}{|c|c|}
\hline Floral Origin & MGO \\
\hline Citrus & $4.51^{\mathrm{A}}$ \\
\hline Acacia & $8.87^{\mathrm{B}}$ \\
\hline Coriander & $7.29^{B}$ \\
\hline Honeydew & $6.84^{\mathrm{B}}$ \\
\hline Multifloral & $9.92^{B C}$ \\
\hline Thistle & $8.49^{B C}$ \\
\hline Thyme & $9.02^{B C}$ \\
\hline Cornflower & $10.28^{C}$ \\
\hline Eucalyptus & $11.64^{\mathrm{C}}$ \\
\hline Almond & $17.88^{\mathrm{D}}$ \\
\hline Sweet Cherry & $18.62^{\mathrm{D}}$ \\
\hline SEM $^{1}$ & 0.88 \\
\hline
\end{tabular}

${ }^{1}$ Standard error of the means. Different letters show statistical differences: ${ }^{\mathrm{A}}, \mathrm{B}, \mathrm{C}, \mathrm{D}=P<0.01$.

Citrus honey showed the lowest concentration of MGO $(P<0.01)$. Cherry and almond honeys, instead, showed the highest concentration of MGO $(P<0.01)$. Moreover, the concentrations of MGO observed in coriander, honeydew and multifloral honey were lower than detected in cornflower and eucalyptus honey $(P<0.01)$.

To our knowledge, this is the first study of MGO assessment in Italian cherry and almond honeys, which showed higher values of MGO compared to the other honey types analyzed. In agreement with previous studies carried out on different types of honey [37,48-50], this study confirms that although the concentrations are much lower than in mānuka honey $(200-800 \mathrm{mg} / \mathrm{kg})$, MGO is frequently also found in other types of honey. In addition, the presence of MGO in variable concentrations within the range 6.9 to $24.1 \mathrm{mg} / \mathrm{kg}$ in cherry and almond floral honey could confirm that this high variability may be linked to the flora involved, to seasonality, to geographical area, as well as to the susceptibility of this parameter to different factors.

\section{Discussion}

Honey has always been a natural product highly appreciated for its sweet taste and its nutritional properties. The increased demand for honey by consumers is due to the several medicinal uses/attributes that this food has been proven to have throughout the history of mankind [51]. Some researchers have focused on the phytochemical compound MGO, which is responsible for the powerful antibacterial activity in mānuka and other types of honey [37,48-50].

The different levels of MGO in the honey samples investigated could be associated with technological ultrafiltration and thermal processes, which could influence the chemical transformation of DHA into MGO. The conversion of the DHA dimer into a reactive monomer, for subsequent MGO formation, is probably facilitated by various compounds, such as phenolic and amino acids. The ultrafiltration process, applied in honey for commercial purposes, could affect the content of these compounds. Adams et al. [36] showed experimentally that the processes of MGO formation are significantly accelerated by adding amino acids, such as lysine or arginine, to honey.

Furthermore, low levels of MGO could occur if phenolic acids and amino acids cause the removal of both DHA and MGO by Maillard-type side reactions, either by acting in a 
catalytic capacity or by direct reaction [52]. Finally, the variability in MGO concentration could therefore be due to a reduced presence of DHA in fresh honey. Therefore, botanical and geographical origin greatly affect the chemical composition of honey and its medicinal properties $[53,54]$. Environmental parameters have a great impact on nectar composition and, consequently, on the levels of DHA in plant nectar. Under conditions of abiotic stress, plants develop a series of defense mechanisms as part of their adaptation strategies, including the production of MGOs. At low concentrations, MGO carries out beneficial activities in the plant, but strong abiotic stresses increase its concentration to toxic levels, with possible damage to cells, such as in proteins, DNA, RNA and lipids [55,56].

MGO is a molecule with ambivalent properties, so its high concentrations in mānuka honey could be suitable only for certain purposes. For example, mānuka honey seems to be very effective at healing wounds. Wound-healing is a complex process involving the interaction of a cascade of cellular events. In chronic wounds, bacteria are often enclosed within the biofilm, where cells are encapsulated in a polysaccharide matrix and other components that limit the effects of antibiotics on wound-healing.

In addition, honey has other benefits due to its physical properties against bacterial growth. The combination of antibacterial and anti-inflammatory activity within honey promotes the healing of chronic wounds. Moreover, additional anti-inflammatory properties have been observed, such as the prevention of the prolonged inflammatory response by suppressing the production and propagation of inflammatory cells at the wound site, and by stimulating the production of pro-inflammatory cytokine, allowing normal healing to occur and stimulating the proliferation of fibroblasts and epithelial cells [53]. Healing times after honey treatment have been observed, and seem to be shorter than for conventional treatments [57].

Despite the high level of MGO in mānuka, honey has shown good efficacy in the treatment of chronic wounds. Its effects on the treatment of ulcers in diabetic subjects have not yet been properly investigated, probably due to the risk of indirectly forming AGEs, which could impair the wound-healing process [57].

Considering that the information concerning the potential toxicity of dietary MGO is ambivalent, and that high doses could theoretically be toxic to mammalian cells, mānuka honey may now be more suitable for topical application as a natural remedy for woundhealing. Further studies to understand the possible benefits or the physiological implications of the high concentrations of MGO present in mānuka honey are therefore necessary.

Although the presence of MGO in honey has greatly attracted the attention of the international scientific community for its biological properties, it is necessary to discriminate the sources from which it is derived and the potential therapeutic applications of honeys, other than mānuka honey, with high concentrations of MGO.

The preliminary data collected in this survey show that MGO levels in Italian honeys are very different and are potentially related to the cultivar considered. We can assume that these different levels of MGO could also result from a natural variability in the amount of DHA in the nectar, and that specific cultivars, such as cherry and almond trees typical of Apulia, have the potential to produce honeys with high levels of MGO. In this regard, it is therefore necessary to specifically analyze the DHA contents of cherry and almond nectars to promote the opportunity for selective breeding, obtaining trees with high levels of dihydroxyacetone in the nectar.

Geographical and botanical origins play prominent roles in the bioavailability of bioactive nutraceutical/functional therapeutic compounds. Moreover, further investigations into MGO concentration in a greater number of samples and types of Apulian honey are required.

\section{Conclusions}

Our results demonstrate that some unifloral Apulian honey contains high levels of MGO if compared with other Italian honeys. Starting from these preliminary data, it is necessary to investigate the origin of the $\mathrm{MGO}$ and the antibacterial properties of these 
honeys by carrying out a careful in vitro evaluation of the mechanisms responsible for their biological activities, so as to discriminate the antimicrobial and antioxidant power induced by MGO.

The biological and therapeutic properties of honey are not expressed by a single component, but are the result of the synergism of all molecules and chemical compounds that characterize it. With its particular chemical and physical properties, honey may be a valid alternative substance for clinical use. Therefore, further studies are needed to understand the clinical efficacy of honeys with different MGO concentrations. Finally, if honey is to be used in medical practice, its standardization and quality assurance both become necessary.

Author Contributions: Conceptualization, E.B.; formal analysis, E.C.; investigation, A.E.S., A.M. and P.M.; data curation, G.B. and R.B.; writing-original draft preparation, V.T.; writing-review and editing, E.B.; project administration, A.D.P.; frunding acquisition, G.T. and E.B. All authors have read and agreed to the published version of the manuscript.

Funding: This research was financially supported by Regione Puglia (Department of Agriculture, Rural Development and Environment-Section of competitiveness of food supply chains): Research and Experimentation Project in Agriculture "Ape e Ambiente: Biomonitoraggio e Valorizzazione dei Prodotti dell'alveare Pugliesi” (AP.A.Bi.Va.P.P.) (Cod PSR_115). Regulation (EU) No 1308/2013 of the European Parliament and of the Council of 17 December 2013, financing of aid applications 2018.

Institutional Review Board Statement: Not applicable.

Informed Consent Statement: Not applicable.

Data Availability Statement: Not applicable.

Acknowledgments: The authors thank Stefano Sportelli for providing invaluable technical assistance in the chemistry laboratory. Thanks to URAAPI for providing samples from Apulia Region.

Conflicts of Interest: The authors declare no conflict of interest.

\section{References}

1. Biluca, F.C.; Braghini, F.; Gonzaga, L.V.; Costa, A.C.O.; Fett, R. Physicochemical profiles, minerals and bioactive compounds of stingless bee honey (Meliponinae). J. Food Compost. Anal. 2016, 50, 61-69. [CrossRef]

2. Cornara, L.; Biagi, M.; Xiao, J.; Burlando, B. Therapeutic properties of bioactive Compounds from different honeybee products. Front. Pharmacol. 2017, 8, 1-20. [CrossRef] [PubMed]

3. Viuda-Martos, M.; Ruiz-Navajas, Y.; Fernández-López, J.; Pérez-Álvarez, J.A. Functional properties of honey, propolis, and royal jelly. J. Food Sci. 2008, 73, 117-124. [CrossRef] [PubMed]

4. Alvarez-Suarez, J.M.; Tulipani, S.; Romandini, S.; Bertoli, F.; Battino, M. Contribution of honey in nutrition and human health: A review. Med. J. Nutr. Metab. 2010, 3, 15-23. [CrossRef]

5. Israili, Z.H. Antimicrobial properties of honey. Am. J. Ther. 2014, 21, 304-323. [CrossRef] [PubMed]

6. Knight, A. The therapeutic effects of honey. Plymouth Stud. Sci. 2013, 6, 376-385.

7. Manyi-Loh, C.E.; Clarke, A.M.; Ndip, R.N. An overview of honey: Therapeutic properties and contribution in nutrition and human health. Afr. J. Microbiol. Res. 2011, 5, 844-852.

8. Alvarez-Suarez, J.M.; Giampieri, F.; Battino, M. Honey as a source of dietary antioxidants: Structures, bioavailability and evidence of protective effects against human chronic diseases. Curr. Med. Chem. 2013, 20, 621-638. [CrossRef] [PubMed]

9. Burlando, B.; Cornara, L. Honey in dermatology and skin care: A review. J. Cosmet. Dermatol. 2013, 12, 306-313. [CrossRef]

10. Ahmed, A.K.; Hoekstra, M.J.; Hage, J.J.; Karim, R.B. Honey-medicated dressing: Transformation of an ancient remedy into modern therapy. Ann. Plast. Surg. 2013, 50, 143-148. [CrossRef]

11. Fischbach, M.A.; Walsh, C.T. Antibiotics for Emerging Pathogens. Science 2009, 325, 1089-1093. [CrossRef] [PubMed]

12. Molan, P.C. The evidence and the rationale for the use of honey as a wound dressing. Wound Pract. Res. 2011, 19, $204-220$.

13. Walsh, C. Antibiotics: Actions, Origins, Resistance; American Society for Microbiology (ASM) Press: Washington, DC, USA, 2003.

14. Alvarez-Suarez, J.M.; Gasparrini, M.; Forbes-Hernández, T.Y.; Mazzoni, L.; Giampieri, F. The Composition and Biological Activity of Honey: A Focus on Mānuka Honey. Foods 2014, 3, 420-432. [CrossRef] [PubMed]

15. Anand, S.; Pang, E.; Livanos, G.; Mantri, N. Characterization of Physico-Chemical Properties and Antioxidant Capacities of Bioactive Honey Produced from Australian Grown Agastache rugosa and its Correlation with Colour and Poly-Phenol Content. Molecules 2018, 23, 108. [CrossRef]

16. Buratti, S.; Benedetti, S.; Cosio, M.S. Evaluation of the antioxidant power of honey, propolis and royal jelly by amperometric flow injection analysis. Talanta 2007, 71, 1387-1392. [CrossRef] 
17. Ferreirra, I.C.F.R.; Aires, E.; Barreira, J.C.M.; Estevinho, L.M. Antioxidant activity of Portuguese honey samples: Different contributions of entire honey and phenolic extract. Food Chem. 2008, 114, 1438-1443. [CrossRef]

18. Gheldof, N.; Wang, X.H.; Engeseth, N.J. Identification and quantification of antioxidant components of honeys from various floral sources. J. Agric. Food Chem. 2002, 50, 5870-5877. [CrossRef]

19. Petretto, G.L.; Cossu, M.; Alamanni, M.C. Phenolic content, antioxidant and physico-chemical properties of Sardinian monofloral honeys. Int. J. Food Sci. Technol. 2015, 50, 482-491. [CrossRef]

20. Raso, G.M.; Meli, R.; Di Carlo, G.; Pacilio, M.; Di Carlo, R. Inhibition of inducible nitric oxide synthase and cyclooxygenase-2 expression by flavonoids in macrophage J774A.1. Life Sci. 2001, 68, 921-931. [CrossRef]

21. Rossi, A.; Longo, R.; Russo, A.; Borrelli, F.; Sautebin, L. The role of the phenethyl ester of caffeic acid (CAPE) in the inhibition of rat lung cyclooxygenase activity by propolis. Fitoterapia 2002, 73, 30-37. [CrossRef]

22. Albaridi, N.A. Antibacterial potency of honey. Int. J. Microbiol. 2019, 2019, 10. [CrossRef] [PubMed]

23. Saranraj, P.; Sivasakthi, S. Comprehensive review on honey: Biochemical and medicinal properties. J. Acad. Ind. Res. 2018, 6, 165-181.

24. Bucekova, M.; Sojka, M.; Valachova, I.; Martinotti, S.; Ranzato, E.; Szep, Z.; Majtan, J. Bee-derived antibacterial peptide, defensin-1, promotes wound reepithelialisation in vitro and in vivo. Sci. Rep. 2017, 7, 7340. [CrossRef]

25. Bucekova, M.; Jardekova, L.; Juricova, V.; Bugarova, V.; Di Marco, G.; Gismondi, A.; Leonardi, D.; Farkasovska, J.; Godocikova, J.; Laho, M.; et al. Antibacterial activity of different blossom honeys: New findings. Molecules 2019, 24, 1573. [CrossRef] [PubMed]

26. Nolan, V.C.; Harrison, J.; Cox, J.A.G. Dissecting the antimicrobial composition of honey. Antibiotics 2019, 8, 251. [CrossRef]

27. Price, C.L.; Knight, S.C. Methylglyoxal: Possible link between hyperglycaemia and immune suppression? Trends Endocrinol. Metab. 2009, 20, 312-317. [CrossRef]

28. Zhang, S.; Jiao, T.; Chen, Y.; Gao, N.; Zhang, L.; Jiang, M. Methylglyoxal induces systemic symptoms of irritable bowel syndrome. PLOS ONE 2014, 9, e105307. [CrossRef]

29. Rückriemen, J.; Hohmann, C.; Hellwig, M.; Henle, T. Unique fluorescence and high-molecular weight characteristics of protein isolates from mānuka honey (Leptospermum scoparium). Food Res. Int. 2017, 99, 469-475. [CrossRef]

30. Bulman, S.E.L.; Tronci, G.; Goswami, P.; Carr, C.; Russell, S.J. Antibacterial properties of nonwoven wound dressings coated with mānuka honey or methylglyoxal. Materials (Basel) 2017, 10, 954.

31. Cooper, R.; Jenkins, L.; Rowland, R. Inhibition of biofilms through the use of mānuka honey. Wounds UK 2011, 7, $24-32$.

32. Jervis-Bardy, J.; Foreman, A.; Bray, S.; Tan, L.; Wormald, P.J. Methylglyoxal-infused honey mimics the anti-Staphylococcus aureus biofilm activity of mānuka honey: Potential implication in chronic rhinosinusitis. Laryngoscope 2011, 121, 1104-1107. [CrossRef] [PubMed]

33. Kwakman, P.H.S.; te Velde, A.A.; de Boer, L.; Vandenbroucke-Grauls, C.M.J.E.; Zaat, S.A.J. Two major medicinal honeys have different mechanisms of bactericidal activity. PLoS ONE 2011, 6, 17709. [CrossRef] [PubMed]

34. Clearwater, M.J.; Revell, M.; Noe, S.; Manley-Harris, M. Influence of genotype, floral stage, and water stress on floral nectar yield and composition of mānuka (Leptospermum scoparium). Ann. Bot. 2018, 121, 501-512. [CrossRef] [PubMed]

35. Weigel, K.U.; Opitz, T.; Henle, T. Studies on the occurrence and formation of 1,2-dicarbonyls in honey. Eur. Food Res. Technol. 2004, 218, 147-151. [CrossRef]

36. Adams, C.J.; Manley-Harris, M.; Molan, P.C. The origin of methylglyoxal in New Zealand mānuka (Leptospermum scoparium) honey. Carbohydr. Res. 2009, 344, 1050-1053. [CrossRef]

37. Mavric, E.; Wittmann, S.; Barth, G.; Henle, T. Identification and quantification of methylglyoxal as the dominant antibacterial constituent of Mānuka (Leptospermum scoparium) honeys from New Zealand. Mol. Nutr. Food Res. 2008, 52, 483-489. [CrossRef]

38. Williams, S.; King, J.; Revell, M.; Manley-Harris, M.; Balks, M.; Janusch, F.; Dawson, M. Regional, annual, and individual variations in the dihydroxyacetone content of the nectar of mānuka (Leptospermum scoparium) in New Zealand. J. Agric. Food Chem. 2014, 62, 10332-10340. [CrossRef]

39. Council EU. Council Directive 2001/110 Relating to Honey. Off. J. Eur. Communities L 2002, 10, 47-52.

40. AOAC. Official Method of Analysis, 19th ed.; Association of Official Analytical Chemists: Washington, DC, USA, 2012.

41. International Honey Commission. Harmonized Methods of the International (European) Honey Commission; $2009 ;$ pp. 1-63. Available online: https:/ / www.ihc-platform.net/ihcmethods2009.pdf (accessed on 18 November 2020).

42. Escriche, I.; Visquert, M.; Juan-Borras, M.; Fito, P. Influence of simulated industrial thermal treatments on volatile fractions of different varieties of honey. Food Chem. 2009, 112, 329-338. [CrossRef]

43. Chirife, J.; Zamora, M.C.; Motto, A. The correlation between water activity and \% moisture in honey: Fundamental aspects and application to Argentine honeys. J. Food Eng. 2006, 72, 287-292. [CrossRef]

44. Wedmore, E. The accurate determination of the water content of honeys. Bee World 1955, 36, 197-206. [CrossRef]

45. AOAC. Official Methods of Analysis, 15th ed.; Association of Official Analytical Chemists: Arlington, VA, USA, 1990.

46. Bogdanov, S.; Ruoff, K.; Persano Oddo, L. Physico-chemical methods for the characterisation of unifloral honeys: A review. Apidologie 2004, 35, 4-17. [CrossRef]

47. Oddo, L.P.; Piazza, M.G.; Pulcini, P. Invertase activity in honey. Apidologie 1999, 30, 57-65. [CrossRef]

48. Arena, E.; Ballistreri, G.; Tomaselli, F.; Fallico, B. Survey of 1,2-dicarbonyl compounds in commercial honey of different floral origin. J. Food Sci. 2011, 76, 1203-1210. [CrossRef] 
49. Atrott, J.; Haberlau, S.; Henle, T. Studies on the formation of methylglyoxal from dihydroxyacetone in Mānuka (Leptospermum scoparium) honey. Carbohydr. Res. 2012, 361, 7-11. [CrossRef]

50. Salonen, A.; Virjamo, V.; Tammela, P.; Fauch, L.; Julkunen-Tiitto, R. Screening bioactivity and bioactive constituents of Nordic unifloral honeys. Food Chem. 2017, 237, 214-224. [CrossRef]

51. Ahmed, S.; Sulaiman, S.A.; Baig, A.A.; Ibrahim, M.; Liaqat, S.; Fatima, S.; Jabeen, S.; Shamim, N.; Othman, N.H. Honey as a potential natural antioxidant medicine: An insight into its molecular mechanisms of action. Oxid. Med. Cell. Longev. 2018, 2018, 8367846. [CrossRef]

52. Grainger, M.N.C.; Manley-Harris, M.; Lane, J.L.; Field, R.J. Kinetics of conversion of dihydroxyacetone to methylglyoxal in New Zealand mānuka honey: Part I-Honey systems. Food Chem. 2016, 202, 484-491. [CrossRef]

53. Irish, J.; Blair, S.; Carter, D.A. The Antibacterial Activity of Honey Derived from Australian Flora. PLoS ONE 2011, 6, e18229. [CrossRef]

54. Kilty, S.J.; Duval, M.; Chan, F.T.; Ferris, W.; Slinger, R. Methylglyoxal: (active agent of mānuka honey) in vitro activity against bacterial biofilms. Int. Forum Allergy Rhinol. 2011, 1, 348-350. [CrossRef]

55. Al-Mamarya, M.; Al-Meerib, A.; Al-Habori, M. Antioxidant activities and total phenolics of different types of honey. Nutr. Res. 2002, 22, 1041-1047. [CrossRef]

56. Windsor, S.; Pappalardo, M.; Brooks, P.; Williams, S.; Manley-Harris, M. A convenient new analysis of dihydroxyacetone and methylglyoxal applied to Australian Leptospermum honeys. J. Pharmacogn. Phytother. 2012, 4, 6-11. [CrossRef]

57. Majtan, J. Methylglyoxal— A potential risk factor of mānuka honey in healing of diabetic ulcers. Evid. Based Complement. Altern. Med. 2011, 2011, 295494. [CrossRef] [PubMed] 